EASTERN REVIEW 2017, T. 6

Agata Włodarska-Frykowska

\title{
Migration processes in the Baltic States - the dynamic of change
}

\section{Introduction}

Migration processes are one of the most important topics of political discussion in contemporary Europe ${ }^{1}$. On one hand there is an intensive flow of immigrants to Europe from Syria, Afghanistan, Iraq, Kosovo, Pakistan, Eritrea and many others creating a serious division between the EU members over the problem of resetting refuges ${ }^{2}$. On the other hand huge migration movements are observed inside Europe. Inhabitants of central and eastern UE member states want to increase their standard of living looking for new chances and job opportunities abroad. In the case of Estonia, Latvia and Lithuania such migration movements seem to be very dangerous for societies drastically reducing the number of inhabitants of three states which are very poorly inhabited. Demographic problems and regular migrations are stated to be quite troubled for the Baltic States.

History of Estonia, Latvia and Lithuania was always quite complicated. From 1940 till the end of 1991 they were the parts of the Soviet Union without stronger influence on domestic politics. Since 1950s the three states had become the parts of soviet industrialization project combined with high migration flow. The drastic changes in Baltic societies were the result of introduced migration movements,

${ }^{1}$ G. Lahav, Immigration and Politics in the New Europe Reinventing Borders, Oxford 2015, p. 32-34.

${ }^{2}$ It is reported that more than one million refugees and migrants came to Europe in 2015. Asylum claims were made in Germany, (Germany was recognized by immigrants as a state with simple system of counting newcomers), Belgium, the Nederland's, Great Britain, Sweden, Finland, Italy, Spain, Hungary, Poland and many others. Eurostat, http://ec.europa.eu/eurostat/web/asylumand-managed-migration/statistics-illustrated (20.08.2016). 
not counting increasing population of ethnic Russians and Russian speakers and shrinking number of the indigenous inhabitants.

The purpose of the article is to answer a question regarding the labor market in the Baltic States and number of immigrants making asylum claims as well as evaluating the migration processes of ethnic Estonians, Latvians and Lithuanians. Up to now, the number and status of ethnic Russians, especially in Estonia and Latvia drastically influences on the job market and social relations. In the context of such difficult history and huge ethnic division into the societies, the questions regarding new immigrants and their status is considered to be even more difficult to be answered. Are the Baltic States popular destinations for immigrants and how do they influence on the society and economy of the states? How does the rate of migration influence the labour market? Are there any tools that encourage residents of Estonia, Latvia and Lithuania to stay in their origin states? New migration movements created new situations for social, political and economic situations in the states. All of them have to face new reality.

\section{Migrations to the Baltic States}

Recent history of the Baltic States still plays a very significant role in shaping the relations in the Baltic societies and creating the attitude to immigration and integration policy. The needs of industrialization, especially visible in Estonia, were the main factor to build in-immigration from all parts of the Soviet Union. One of the examples is that the place of employment was assigned for specialists and experts after their graduation. Such prescription was rather impossible to be changed. It is worth mentioning that Estonian society is reported to be intolerant toward immigrants. Lack of tolerance is a feature of both native Estonians as well as old immigrants, mostly Russians. What is more, especially visible immigrants such as Muslims are not warmly welcomed. Racists attacks take place in Tallinn or Tartu but are not often reported, verbal insults are the forms of intolerant and aggressive behavior towards newcomers and national minorities living on the territory of the state ${ }^{3}$. The immigration situation in Latvia seems to be quite similar to Estonian. Since regaining independence in 1991 social integration processes are defined as absolutely imperative and important. But only the former citizens, before soviet occupation in 1940, and descendants of theirs were allowed to obtain the citizenship of the state. In Lithuania immigration situation before 1990 was not as complicated as in the other two Baltic States. All inhabitants living on the

3 J. Kovalenko, Situation of new immigrants in Estonia, New immigrants in Estonia, Latvia and Lithuania, Legal Information Centre for Human Rights, Tallinn 2010, p. 7-8. 
territory of the state we given Lithuanian citizenship without any extra tests and long naturalization process as it was in the case of Estonia and Latvia ${ }^{4}$.

Up to now societies of the Baltic States are strongly divided taking into consideration ethnicity. Lithuania is the most homogenous state with almost $85 \%$ of ethnic Lithuanians. In Estonia and Latvia the ethnic division is wider. The society of contemporary Estonia consists of almost $68 \%$ of ethnic Estonians and in $25 \%$ of Russian minority members. In Latvia the ethnic situation seems to be similar, $60 \%$ of ethnic Latvians and $28 \%$ of Russian minority members. Such a high number of Russians is a direct result of migration in the soviet times.

Table 1. Composition of contemporary Lithuanian society (2011)

\begin{tabular}{|c|c|}
\hline Ethnicity & Nr of population (\%) \\
\hline Lithuanians & 84,2 \\
\hline Poles & 6,7 \\
\hline Russians & 5,8 \\
\hline Byelorussians & 1,2 \\
\hline Ukrainians & 0,5 \\
\hline Others & 1,6 \\
\hline
\end{tabular}

Source: Population and social statistics, 15.03.2013, Statistics Lithuania, Lithuanian 2011 Population Census in Brief, http://osp.stat.gov.lt/ (20.06.2016).

Table 2. Composition of Latvian society $(2000,2009)$

\begin{tabular}{|c|c|c|}
\hline Ethnicity & Nr of population 2000 (\%) & Nr of population 2009 (\%) \\
\hline Latvians & 57,7 & 59,3 \\
\hline Russians & 29,6 & 27,8 \\
\hline Belarusians & 4,1 & 3,6 \\
\hline Ukrainians & 2,7 & 2,5 \\
\hline others & 5,9 & 6,8 \\
\hline
\end{tabular}

Source: Latvijas 2000. gada tautas skaitīšanas rezultāti. Statistikas datu krājums (2002). Rīga: Latvijas Republikas. Centrālā statistikas pārvalde, Demogrāfi ja 2009 (2009) Statistisko datu krājums. Rìga: LR Centrālā statistikas pārvalde.

${ }^{4}$ P.M. Afrolat, Situation of new immigrants in Latvia, New immigrants in Estonia, Latvia and Lithuania, Legal Information Centre for Human Rights, Tallinn 2010, p. 25-26. 
Table 3. Composition of Estonian society

(2015)

\begin{tabular}{|c|c|}
\hline Ethnicity & Population (\%) \\
\hline Estonians & 69,7 \\
\hline Russians & 25,2 \\
\hline Ukrainians & 1,7 \\
\hline Belarusians & 0,9 \\
\hline Finnish & 0,6 \\
\hline others & 1,9 \\
\hline
\end{tabular}

Source: Eesti statistika aastaraamat

2015, Statistical Year Book, Tallinn 2015.

Quite often Estonia, Latvia and Lithuania are treated as one organism with rather similar social, political and economic problems. It has to be underlined that those three countries have to be analyzed separately with their own local specificity. The current immigration situation in the Baltic States is analyzed including identification of the migration patterns and number of newcomers. Contemporary immigration to Estonia seems to be rather insignificant. People who decide to come and stay there are mostly from the EU states and former members of the Soviet Union. Those immigrants are not recognizable in the society, this group of inhibitions is called "invisible immigrants". In 2014 almost 4000 persons come to Estonia but this number is smaller by $30 \%$ in comparison to the previous years. According to the statistics $44 \%$ of immigrants are women. Immigrants arriving in Estonia mostly come from a neighbor state Finland but also from Russia, Ukraine, Germany, Sweden, Latvia. Thus, not many decide to come from non-European countries. Estonia is not a promised land to asylum seekers and refugees. In years 1997-2009 a majority of the asylum seekers were from Iraq (22), Russia (21), Turkey (17), Belarus (11), Georgia (10), Pakistan, Afghanistan (8), and Nigeria (6) but their number was not spectacular ${ }^{5}$. From 1997 to 2012349 asylum seekers applied in Estonia.

Table 4. Number of asylum seekers in Estonia

\begin{tabular}{|c|c|c|c|c|}
\hline Specification & 2008 & 2010 & 2012 & 2015 \\
\hline $\begin{array}{c}\text { Nr of asylum seekers per } \\
100000 \text { residents }\end{array}$ & 14 applications & 30 applications & 77 applications & 18 applications \\
\hline
\end{tabular}

Source: Citizenship and Migration Board, avaiable, http://www.mig.ee/index.php/mg/est/ statistika, (01.07.2015); Eurostat, http://ec.europa.eu/eurost/web/asylum-and-managed-migration/ statistics-illustrated (20.08.2016).

${ }^{5}$ Citizenship and Migration Board, http://www.mig.ee/index.php/mg/est/statistika (01.07.2015). 
In 1997 Estonia joined the UN Convention on the Status of Refugees, it was the beginning of wider protection offered to refuges. Each year more asylum seekers benefit from international help and protection offered by the Estonian Illuka Reception Center ${ }^{6}$. Nowadays there are not any programs aiming at immigrants. The only document was an Integration Strategy, the first launched in 2000, the second in 2008 and the third initiated in 2014 till 2010. The aim of the strategies is to underline areas of social integration taking into consideration social, economic and political context, on the other hand they are discuss quite general problems not indicial or local one. Following that they are rather directed to old immigrants living in Estonia than to newcomers. State support in the field of education is the most visible. Pupils and students who do not speak Estonian are given help with a language to better participate in the process of education and deepen integration process into the society. The other incentive are special projects carried by Migration Foundation, however there is still a problem for employers with gaining information regarding legal employment of refuges and asylum seekers ${ }^{8}$.

Latvia, similarly to Estonia, does not host many new immigrants. The reasons are connected with school and work environment that is not favorable for immigrants. The state has not introduced any policy aiming at integrating immigrants and launching actions helping them to integrate into the Latvian society. Temporary residents of Latvia have access to the labour market but with some limits. They can be hired only by one employer with further regulations to a job position that is prohibited to be changed. The other aspect is that the immigrants who lost their job have to leave the state. When finding new employment a new job permission must be applied. Those regulations are also combined for employers who have to take care of many details as vacancy advertisement not shorter than for a month if they want to employ an immigrant and submit all needed documents on time, what discourages them from this

${ }^{6}$ Residents of the Center are given individual support and various forms of activities, it is also a form of integration with the society. Illuka Reception Center cooperates with the Ministry of Social Affairs and some civil organizations. Pagulasseisundi konventsioon [UN Convention on the Status of Refugees]. Available at: https://www.riigiteataja.ee/akt/78623 (21.08.2016).

7 Integration and Migration Foundation implements a number of projects aiming at improving Estonian Language skills, teaching tolerance, underlining equal treatment and helping to get better skills for unemployed. An important project Uus kodu (New home) was carried by the Migration Foundation from April 2007 to August 2008. Its goal was to improve Language communication skills and organize orientation courses on Estonian culture with elements of history and legislation rules. The big disadvantage of the presented project was the limited target group. Only Russians speakers could participate in that what excluded almost all new emigrants. Some other initiatives with English language classes were also launched, but they occurred to be to expansive because the number of students was not big, thus they were quickly given up.

${ }^{8}$ Estonian Integration Strategy 2008-2013, Tallinn 2008. 
form of employment. If the immigrant is guaranteed a stable job, they can get a temporary residence status for up to five years 9 .

In years 1998-2011, 472 asylum seekers requested a permission to stay in Latvia. Even if the number of applicants is not spectacular, it is much more than in previous years. Some years ago the main reason for migration was family reunification, staying with family, parents, spouses made people come to Latvia. Later, especially from 2008 to 2010 , possibilities of being employed in transport, logistics or industry influenced the decision of migration. Before 2007 many immigrants worked in building sector, about 36\%, after 2010 only 3\%. Nowadays the number of applications is increasing, what is strongly connected with new investments in Latvia. Russians, Ukrainians, Byelorussians and Kazakhs the most often apply for the status of permanent citizens, investments in real estate and credit institutions are the most common reasons for permissions. New regulations introduced in September 2014 limited the number of permanent residence applicants, the value of the property cannot be lower than 250000 euro, what is more $5 \%$ of the real estate value has to be paid to the state budget ${ }^{10}$.

Table 5. Number of asylum seekers in Latvia

\begin{tabular}{|c|c|c|c|c|}
\hline Specification & 2004 & 2008 & 2012 & 2013 \\
\hline $\begin{array}{c}\text { Nr of asylum } \\
\text { seekers }\end{array}$ & 7 applications & 51 applications & 189 applications & 185 applications \\
\hline
\end{tabular}

Source: Structure of migration and asylum policy in Latvia, raport, Riga 2011, Eurostat; http:// ec.europa.eu/eurostat/web/asylum-and-managed-migration/statistics-illustrated (20.08.2016).

Table 6. Number of first time resident permissions in Latvia

\begin{tabular}{|c|c|c|c|c|c|c|c|c|}
\hline Specification & 2006 & 2007 & 2008 & 2009 & 2010 & 2011 & 2012 & 2013 \\
\hline FTT & 2928 & 4831 & 2116 & 2388 & 2495 & 4824 & 6365 & 7353 \\
\hline FTP & 3238 & 2484 & 2116 & 2598 & 6123 & 3264 & 2948 & 3089 \\
\hline
\end{tabular}

FTT- first time permission temporary. FTP - first time permission permanent.

Source: Latvian Office of Citizenship and Migration Affairs, http://www.pmlp.gov.lv/en/home/ statistics/residence-permits.html (11.09.2016).

9 The cabinet of Ministers regulations Nr. 116 Procedure for employing foreigners and stateless persons in Latvia, in effect since 01.04.2000, with amendments prior to 07.08.2001.

${ }^{10}$ Before September 2014 the value of the property had to be from 71000 to 140000 euro, now this price is doubled. 
Table 7. Number of valid resident permissions in Latvia

\begin{tabular}{|c|c|c|c|c|c|c|c|c|c|}
\hline Specification & 2006 & 2007 & 2008 & 2009 & 2010 & 2011 & 2012 & 2013 & 2014 \\
\hline VP & 29487 & 30820 & 33055 & 34354 & 36249 & 42054 & 44328 & 46308 & 48137 \\
\hline VT & 8003 & 96569 & 12815 & 14715 & 13785 & 13557 & 15957 & 19930 & 23857 \\
\hline
\end{tabular}

$\mathrm{VP}$ - valid permanent permissions, VT - valid temporary permissions.

Source: Latvian Office of Citizenship and Migration Affairs, http://www.pmlp.gov.lv/en/home/ statistics/residence-permits.html (11.09.2016).

The number of residents of Latvia is slightly increasing what is strongly connected with job opportunities. It is especially important for permanent residents who can benefit from a full spectrum of rights including easier access to employment, better job conditions, tax benefits and better access to public service. All of those rights are extended to the members of the family. The other issue is the problem of discrimination that is quite serious in Latvia, immigrants are exposed to many unexpected situations and the risk of being unemployed or losing a job is rather high. Even if they are well educated and qualified, they are paid less and suffer from lower social benefits.

Similarly to Estonia and Latvia, Lithuania is getting more popular among immigrants as a destination place. Thus, the topic of migrations receives wider attention and public interest. The annual average of immigrants is not spectacular, in 20153700 people decided to stay in Lithuania, mostly they are from non-European Union countries, approximately 2900 people, the minority, approximately 800 , comes from the European Union states. The biggest number of newcomers emigrates from Belarus, Russia and Ukraine. 41000 residents living in Lithuania was registered in January 2016, it gives a little better result than in 2015 but only by 300 people. Some residing foreigners are family members of people engaged in business in the state, workers and students ${ }^{11}$. Gaining civil and political rights seems to be the issues that is very important to immigrants. Only immigrant who possess citizenship are full participants of political life. Those immigrants who stay in Lithuania and are the holders of temporary or permanent residence permission have a limited access to political and social participation.

Apart from social and political participation, the attitude towards foreigners is an important factor creating atmosphere for newcomers. First and foremost, the negative attitude in the society has been changing over time. Chechens and Muslims are reported to be the most disliked by native inhabitants, mainly by their origin and religion. Direct attracts against immigrants are not often registered, they are rather occasional.

${ }^{11}$ Lietuvovs Statistikos Dematamentos, http://123.emn.lt/ (30.08.2016). 
Table 8. Number of work permissions in Lithuania

\begin{tabular}{|c|c|c|c|c|c|c|c|c|c|}
\hline Specification & 2004 & 2005 & 2007 & 2008 & 2010 & 2012 & 2013 & 2014 & 2015 \\
\hline WP & 877 & 1565 & 5686 & 7819 & 1808 & 4627 & 5036 & 5382 & 6873 \\
\hline
\end{tabular}

Source: Lietuvovs Statistikos Dematamentos, http://123.emn.lt/ (29.08.2016).

Table 9. Number of foreigners living in Lithuania

\begin{tabular}{|c|r|r|r|r|}
\hline Country & 2011 & 2012 & 2013 & 2014 \\
\hline Klaipèda & 4126 & 4647 & 4673 & 4990 \\
\hline Kaunas & 4417 & 3620 & 3526 & 4143 \\
\hline Marijampole & 404 & 394 & 364 & 418 \\
\hline Alytus & 835 & 798 & 863 & 1113 \\
\hline Panevėžys & 942 & 815 & 824 & 954 \\
\hline Šiauliai & 1811 & 1719 & 1720 & 2215 \\
\hline Tauragė & 295 & 246 & 260 & 280 \\
\hline Telšiai & 720 & 641 & 578 & 619 \\
\hline Utena & 4123 & 2991 & 2849 & 2884 \\
\hline Vilnius & 11928 & 14650 & 15184 & 19717 \\
\hline
\end{tabular}

Source: Lietuvovs Statistikos Dematamentos, http://123.emn.lt/ (29.08.2016).

According to the Geneva Convention the Baltic States are obligated to grant protection to immigrants whose war made leave their states. Forms of asylum are different, there three that are often distinguished. The first one is refugees status what allows to get the status of permanent resident, the second is subsidiary protection, usually given for two years, after that time it can be extended. The third one is temporary protection, this form can be granted in the situation of massive influx of newcomers ${ }^{12}$. In 2015 Europe was touched by huge number of asylum applicants but in the case of Lithuania number of asylum seekers did not drastically increase, in 2014 most applications were from Georgia, Ukraine and Russia.

The growing number of immigrants, including transit migration of people migrating from the East to the West, made the Baltic States provide proper and better working legal system ${ }^{13}$. What is more, legislation adopted from the

${ }^{12}$ Handbook on European law relating to asylum, borders and immigration, European Union Agency for Fundamental Rights, Luxemburg 2014, p. 35-37.

${ }_{13}$ R. Byrne, G. Noll, J. Vedsted-Hansen, Understanding Refugee Law in an Enlarged European Union, "European Journal of International Law” 2014, vol. 15, no. 2, p. 355-379. 
soviet times had to be changed and modernized to be adjusted to the European Union regulations ${ }^{14}$. Lithuania was the first state, before Estonia and Latvia, that joined the international refugee system ${ }^{15}$. Even though there were some initial imperfections of adapted asylum system, the accession to the European Union structures encouraged Estonia, Latvia and Lithuania to develop further advanced protection ${ }^{16}$.

To sum up the numbers of asylum seekers and refugees in the European Union, Estonia, Latvia and Lithuania stand out as EU members with the lowest number of applications. It is a direct result of strict migration procedures and the lack of alternative admission regulations. Estonia has the lowest number of asylum claims. In 2012 only 75 applicants applied for asylum in Tallinn, it gives quite a poor result of 55 claims per 1 million citizens ${ }^{17}$. The data from 2015 illustrate that Lithuania had the lowest number of claims, 11 per 100000 inhabitants, holding the 28th position in Europe, 32 states were checked. Estonia and Latvia had 18 and 17 applications per 100000 inhabitants that time. The leaders in Europe were: Hungary, Sweden, Austria, Norway, Finland and Germany.

Estonia, Latvia and Lithuania have been reported as states of asylum, but after analyzing the number of applications, it is clearly seen that in the migration processes asylum seekers are only a small part of immigrants. Low level of immigration into the Baltic States is combined with the rate of unemployment and economic decline ${ }^{18}$. The number of old immigrants coming from post-soviet space strongly influences the structure of today's Baltic societies. Ethnic division and domestic problems with immigrants determinates the migration policy and strict examination of immigrants applications.

${ }^{14}$ A. Grigas, A. Kasekamp, K. Maslauskaite, L. Zorgenfreija, The Baltic States in the EU: yesterday, today and tomorrow, Notre Europe 2013, Jacques Delors Institute, www.notre-europe. $\mathrm{eu} / \mathrm{media} / \mathrm{balticstateseugrigaskasekampmaslauskaitezorgenfreija-ne-jdi-july13.pdf?pdf=ok}$. (30.12.2015).

15 The Geneva Convention and New York Protocol was ratified by Lithuania on $21^{\text {st }}$ January 1997. Estonia was the second state that ratified the Convention on $19^{\text {th }}$ February 1997, Latvia did the some on $19^{\text {th }}$ June 1997.

16 R. Byrne, G. Noll, J. Vedsted-Hansen, Understanding Refugee Law..., p. 35-37.

${ }^{17}$ In 2012 only Portugal had a worse score, 30 applications for 1 million citizens.

${ }^{18}$ In January 2014 the rate of unemployment in Estonia was 8,7\%, in January $2015-6,3 \%$, in January $2016-6,4 \%$, in June $2016-6,5 \%$. In Latvia, in January 2014 the rate of unemployment was $11,3 \%$, in January $2015-10,2 \%$, in January $2016-9,8 \%$, in July $2016-9,3 \%$. In Lithuania, in January 2014 the rate of unemployment was $11,5 \%$, in January $2015-9,4 \%$, in January $2016-8,6 \%$, in April 2016 - 8,2\%. Trading Economics Unemployment Rate, http://www.tradingeconomics.com (06.09.2016). 
Table 10. Number of asylum seekers applications in 2015

\begin{tabular}{|c|c|c|}
\hline No. & Country & $\begin{array}{c}\text { Number of applications per } \\
10000 \text { inhabitants in the } \\
\text { state }\end{array}$ \\
\hline & Hungary & 1799 \\
\hline 3. & Sweden & 1667 \\
\hline 4. & Austria & 1027 \\
\hline 5. & Norway & 602 \\
\hline 6. & Finland & 591 \\
\hline 16. & Germany & 587 \\
\hline 17. & Italy & 138 \\
\hline 20. & Greece & 122 \\
\hline 21. & Ireland & 71 \\
\hline 22. & Great Britain & 60 \\
\hline 24. & Poland & 32 \\
\hline 25. & Estonia & 18 \\
\hline 28. & Latvia & 17 \\
\hline 32. & Lithuania & 11 \\
\hline 50 & Croatia & 5 \\
\hline
\end{tabular}

Source: Eurostat, http://ec.europa.eu/eurostat/web/asylum-andmanaged-migration/statistics-illustrated (20.08.2016).

\section{Emigration from the Baltic States}

After joining the European Union on May 1, 2004 emigration from Estonia, Latvia and Lithuania increased significantly. Opening of the free labor movement was the main reason of such intensive emigration. Poor employment opportunities resulted in high net migration, over 2000 in Lithuania it was 13\% of population, in Latvia $-9 \%$ and in Estonia 6\%. As a consequence the states lost educated youths, skilled workers and the working-age group was shrinking. Thus, quite numerous diaspora was formed abroad. The first wave of emigration was in 2004, the economic crises in 2008 caused the next movement. The main destinations of migrations were: the Great Britain, Islands, Finland that was mostly chosen by Estonians and Germany that was inhabited by better educated and more experienced emigrants. People between 20-35 years old take a decision to emigrate more often than older citizens. In Latvia and Lithuania better educated and experienced people decide 
to emigrate, very often with their families. The tendency is that more than $50 \%$ of all emigrants are people between 20 and 34 years old, in 2011 it was 55,4\% of all emigrants and those numbers are still increasing. In Estonia emigration pattern seems to be different, single blue collar workers, mostly men look for their job opportunities abroad. Estonian emigrants are often experienced in construction sector $^{19}$. There is also a big group of students who seek their chances abroad. Working abroad is considered to be an alternative after graduates, they prefer to find long-term employment that guarantees gaining experience and skills. Emigrants who come back are usually less educated and the tendency is that after returning they have problems with getting a good job, fulfilling their expectations. Although they have wider experience, they are not paid as they would like to be ${ }^{20}$.

The migrant groups have a crucial impact on the profile of their home states, influencing economy and working groups. There are four distinguished patterns of labour migration processes in Europe that are combined with the process of migration and integration ${ }^{21}$. They are commonly recognized in migration from Central and Eastern Europe to the West $^{22}$. Firstly, what is the strength of emigrants' ties to their home state, secondly what is the strength of the ties to destination state. Those ties can be seen as strong or weak, following that the labour emigration is both changeable and dynamic with visible signs of diversity ${ }^{23}$. Emigrants from the Baltic States are more eager to choose long term emigration that it rather easily changed into permanent stay. $23 \%$ of Latvian who emigrate declare their migration up to 5 years. Migrants who decide to stay in the new place for longer time than 5 years are less likely to return to the country of origin $^{24}$ The tendency is that Latvians have close relations with their destination state than with their home state ${ }^{25}$.

${ }_{19}$ M. Randveer, T. Rõõm, The Structure of Migration in Estonia: Survey-Based Evidence, Working Paper Series, Bank of Estonia 2009, www.eestipank.ee/en/ (11.09.2016).

${ }^{20}$ Coping with Emigration in Baltic and East European Countries, OECD Rapport 2013, p. 11-12.

${ }^{21}$ B.C. Campbell, M.H. Crawford, Perspectives on human migration: Introduction, Causes and Consequences of Human Migration An Evolutionary Perspective, eds B.C. Campbell, M.H. Crawford, Oxford University Press, 2012, p. 2-6.

${ }^{22}$ G. Engbersen, Migration Transitions in an Era of Liquid Migration. Reflections on Fassmann \& Reeger, [in:] Europe: The Continent of Immigrants: Trends, Structures and Policy Implications, ed. M. Okólski, Amsterdam 2012, p. 91-105.

${ }^{23}$ J.H. Friberg, The stages of migration. From going abroad to settling down: Post-accession Polish Workers in Norway, "Journal of Ethnic and Migration Studies" 2013.

${ }^{24}$ V. Kaska, Temporary and Circular Migration: Empirical Evidence, Current Policy Practice and Future Options in Estonia, Estonian Academy of Security Sciences, Tallinn 2010.

${ }^{25}$ V. Kaska, Emigration from Estonia: Recent trends and economic impact, Coping with Emigration in Baltic and East European Countries, OECD Rapport 2013, p. 15-16. 
Table 11. Baltic States emigration

\begin{tabular}{|c|c|c|c|c|c|}
\hline Specification & 2005 & 2007 & 2008 & 2010 & 2011 \\
\hline \multicolumn{6}{|c|}{ ESTONIA } \\
\hline Emigrants & 4610 & 4384 & 4406 & 5294 & 6214 \\
\hline Immigrants & 1436 & 3741 & 3671 & 2810 & 3709 \\
\hline Net migration & -3174 & -643 & -735 & -2484 & -2505 \\
\hline \multicolumn{7}{|c|}{ LATVIA } \\
\hline Emigrants & 2450 & 4183 & 6007 & 10702 & 30380 \\
\hline Immigrants & 1886 & 3541 & 3465 & 2364 & 7253 \\
\hline Net migration & -564 & -642 & -2542 & -8338 & -23127 \\
\hline \multicolumn{7}{|c|}{} & LITHUANIA & \\
\hline Emigrants & 15571 & 13853 & 17015 & 83157 & 53863 \\
\hline Immigrants & 6789 & 8609 & 9297 & 5213 & 15685 \\
\hline Net migration & -8782 & -5244 & -7718 & -77944 & -38178 \\
\hline
\end{tabular}

Source: Eurostat, http://ec.europa.eu/eurostat (20.08.2016).

The population of the Baltic States has been significantly decreasing, to change the trends and encourage young and well-educated people to return to Estonia. The aim of the initiative was to offer people better job conditions in both private and public sector companies. It was directed to the Estonian citizens who graduated from universities in Estonia and emigrated as well as to gradates of other European universities. Elements that are important for young people, firstly good standard of living, secondly, new job challenges and opportunities, thirdly, work environment with international factors. Additionally, living with the family and close to friends was underlined ${ }^{26}$. In Lithuania the highest number of people who emigrate is determinate by their job. In 2007 69,3\% of Lithuanian emigrants left their country to find a better job, later this rate was even higher. The other reason encourages especially young people to emigration was education and possibility to take studies at the foreign university as a full time student or an exchange student. In $200712,6 \%$ of people emigrated because of their education. Universities in Great Britain are quite popular with Lithuanians, University of Glasgow seems be one of the most

26 Talents Back Home was a project launched in October 2010 for two years, run by the Estonian Chamber of Commerce. The project ended in 2012, during that time there were about $4000-4500$ students studying abroad, almost $90 \%$ of them declared that they take into consideration working in Estonia but they need to get a good offer, what is more, time was very important here, just after graduation or possibility to send their children to good Estonian schools. 
often chosen. More than 200 come to Glasgow every year for studies ${ }^{27}$. Among Latvian emigrants situation is similar, $24 \%$ of them were the holders of university degree before 2010. In comparison to the residents of the country the proportions were almost the same. $25 \%$ of inhabitants between 18-74 years old had the diploma of university. Analyzing the economic situation of Latvia return of emigrants is considered to be significant for the future of the state.

The direct consequence of the Baltic States emigration is the negative demographic trend. The introduced programs and projects that aim to encourage people to stay or return to their countries should also investigate both reasons and consequence of emigration. New job opportunities, better tax policy and stimulation of labor demands would help to change and decrease the emigration movements. The state policy should make inhabitants develop themselves and introduce new programs for unemployment increasing their motivation to work. As long as the economic, social and political conditions will not be changed for more favorable better educated and more experienced Estonians, Latvians and Lithuanians will choose western Europe as the place for living and working. The number of outflows will be tend to decline if they see the potential to increase the standard of living, education and health care ${ }^{28}$.

\section{Conclusions}

The problem of migration strongly influences on contemporary Europe. It is especially important to small states coping with the problems of decreasing population as Estonia, Latvia and Lithuania. The Baltic States are often reported to be the states of asylum. It has to be noted that asylum seekers are just a part of wider migration processes taking place nowadays in that part of Europe. The thing is that immigration problems of the Baltic States are relatively smaller in comparison to other members of the European Union, especially to southern European states that are more attractive for refuges. Poor social benefits and quite restrictive immigration law directly connected with ethnic division of societies are considered to be the main reason of such small number of applicants ${ }^{29}$. Thus, the Baltic States are considered to be the transit countries and are not seen as places to

27 University of Glasgow, http://www.gla.ac.uk/international/country/lithuania/ (11.09.2016).

${ }^{28}$ H. de Haas, Engaging Diasporas. How Governments and Development Agencies Can Support Diaspora Involvement in the Development of Origin Countries, International Migration Institute Oxfam 2006, www.heindehaas.com/ Publications/de\%20Haas\%202006\%20-\%20Engaging \%20Diasporas.pdf (10.09.2016).

${ }^{29}$ A. Grigas, A. Kasekamp, K. Maslauskaite, L. Zorgenfreija, The Baltic States in the EU: yesterday, today and tomorrow, Notre Europe, Jacques Delors Institute, 2013, www.notre-europe. eu/media/ (10.09.2016). 
be settled in. The soviet history and relations influence on the situation that some emigrants from the post-soviet space choose the Baltic States emigrating illegally.

At the very beginning of $90,20^{\text {th }}$ century, after regaining independence residents of the Baltic States could easier and faster migrate to Western Europe. Since joining the European Union structures in May 2004 the problem of emigrant movements has been increasing. Some time ago it became the national problem of those three not populated countries. Aging and declining of European societies is long-standing but for states where the rate of emigration is high, it seems to be worse. A first wave of emigration was just after joining European Union, since 2006 for two year stability in emigration movements was visible. Year 2009 brought the next increase in the number of emigrants from Latvia and Lithuania. In Estonia the outflow of emigrants was smaller, what was a direct consequence of milder economic crises and faster recovery. Additionally the number of unemployed in Estonia is lower than in Latvia and Lithuania. The typical Baltic emigrant is young and determined to leave their origin country because of unemployment, is strongly motivated to start a better life abroad with higher salary. The level of education among emigrants is rather balanced, some of the are well-educated white collar workers, the others are blue-collar worker but mostly experienced and trained.

\section{Bibliography}

Afrolat P.M., Situation of new immigrants in Latvia, New immigrants in Estonia, Latvia and Lithuania, Legal Information Centre for Human Rights, Tallinn 2010.

Byrne R., Noll G., Vedsted-Hansen J., Understanding Refugee Law in an Enlarged European Union, "European Journal of International Law" 2014, vol. 15, no. 2.

Causes and Consequences of Human Migration An Evolutionary Perspective, eds B.C. Campbell, M.H. Crawford, Oxford 2012.

Citizenship and Migration Board, http://www.mig.ee/index.php/mg/est/statistika (11.09.2016). Convention on the Status of Refugees, https://www.riigiteataja.ee/akt/78623 (11.09.2016). Coping with Emigration in Baltic and East European Countries, "OECD Rapport" 2013. Eesti statistika aastaraamat 2015, Statistical Year Book, Tallinn 2015.

Engbersen G., Migration Transitions in an Era of Liquid Migration. Reflections on Fassmann \& Reeger, [in:] Europe: The Continent of Immigrants: Trends, Structures and Policy Implications, ed. M. Okólski, Amsterdam 2012.

Estonian Integration Strategy 2008-2013, Tallinn 2008.

Eurostat, http://ec.europa.eu/eurostat/web/asylum-and-managed-migration/statisticsillustrated (11.09.2016).

Friberg J.H., The Stages of Migration. From Going Abroad to Settling Down: Post-accession Polish Workers in Norway, "Journal of Ethnic and Migration Studies" 2013.

Grigas A., Kasekamp A., Maslauskaite K., Zorgenfreija L., The Baltic States in the EU: yesterday, today and tomorrow, Notre Europe 2013, Jacques Delors Institute, www. 
notre-europe.eu/media/balticstateseugrigaskasekampmaslauskaitezorgenfreija-nejdi-july13.pdf?pdf=ok (11.09.2016).

Haas de H., Engaging Diasporas. How Governments and Development Agencies Can

Support Diaspora Involvement in the Development of Origin Countries, International Migration Institute Oxfam 2006, www.heindehaas.com/Publications/de\%20Haas\% 202006\%20-\%20Engaging\%20Diasporas.pdf (11.09.2016).

Handbook on European Law Relating to Asylum, Borders and Immigration, European Union Agency for Fundamental Rights, Luxemburg 2014.

Kaska V., Emigration from Estonia: Recent trends and economic impact, Coping with Emigration in Baltic and East European Countries, OECD Rapport 2013.

Kaska V., Temporary and Circular Migration: Empirical Evidence, Current Policy Practice and Future Options in Estonia, Estonian Academy of Security Sciences, Tallinn 2010.

Kovalenko K., Situation of new immigrants in Estonia, New immigrants in Estonia, Latvia and Lithuania, Legal Information Centre for Human Rights, Tallinn 2010.

Lahav G., Immigration and Politics in the New Europe Reinventing Borders, Oxford 2015. Latvian Office of Citizenship and Migration Affairs, http://www.pmlp.gov.lv/en/home/ statistics/residence-permits.html (11.09.2016).

Lietuvovs Statistikos Dematamentos, http://123.emn.lt/ (11.09.2016).

Lithuanian 2011 Population Census in Brief, http://osp.stat.gov.lt/ (11.09.2016).

Randveer M., Rõõm T., The Structure of Migration in Estonia: Survey-Based Evidence,

Working Paper Series, Bank of Estonia 2009, www.eestipank.ee/en/ (11.09.2016).

Structure of migration and asylum policy in Latvia, Raport, Riga 2011.

University of Glasgow, http://www.gla.ac.uk/international/country/lithuania/(11.09.2016).

\section{Agata Włodarska-Frykowska}

\section{Procesy migracyjne w państwach baltyckich - dynamika zmian}

Artykuł stanowi analizę procesów migracyjnych zachodzących współcześnie w państwach bałtyckich. Estonia, Litwa i Łotwa to kraje, które muszą zmagać się z dużymi problemami demograficznymi, ponadto wysoki poziom emigracji pogłębia niekorzystne trendy. Po wstąpieniu do Unii Europejskiej w 2004 r. możliwości znalezienia lepiej płatnej pracy oraz kontynuacji wykształcenia na uczelniach europejskich zdecydowanie się rozszerzyły. Szczególnie młodzi Bałtowie korzystają z nowych szans i możliwości, co pogłębia proces starzenia się społeczności. Proces imigracji nie jest zbyt intensywny, dotyczy to głównie ludności pochodzenia rosyjskiego, ukraińskiego czy białoruskiego, która decyduje się tutaj na osiedlenie. Zdecydowanie częściej państwa bałtyckie traktowane są jako kraje tranzytowe do krajów Europy Zachodniej.

Słowa kluczowe: procesy migracyjne, emigracja z krajów bałtyckich, imigracja do krajów bałtyckich, społeczeństwa w państwach bałtyckich. 
Агата Влодарска-Фрыковска

\section{Миграционные процессы в балтийских странах - динамика изменений}

Статья представляет собой анализ миграционных процессов, происходящих в настоящее время в балтийских странах. Эстония, Литва и Латвия - страны, которым необходимо справляться с большими демографическими проблемами, а углубляет эти негативные тенденции высокий уровень эмиграции. После вступления в Евросоюз в 2004 году, значительно расширились возможности лучше оплачиваемой работы и продолжения образования в европейских университетах. Пользуются этими возможностями в основном молодые балтийцы, что углубляет процесс старения населения. Процесс иммиграции не интенсивен и касается в основном лиц русского, украинского и белорусского происхождения, которые решаются на постоянное жительство на территории этих стран. Определенно, балтийские страны рассматриваются в основном как транзитные направления в Западную Европу.

Ключевые слова: Миграционные процессы, эмиграция из балтийских стран, иммиграция в балтийские страны, общества в балтийских странах. 